TUGAS PAPER PANCASILA

"PERANG ANTAR SUKU DI PAPUA DIKAITKAN DENGAN TUJUAN NEGARA THE GOOD LIFE, TUJUAN DAN LEGITIMASI NEGARA DAN PIDATO SOEKARNO TENTANG GOTONG ROYONG"

\title{
Dosen Pengampu:
}

Dr. Agustinus W. Dewantara, S.S., M.Hum.

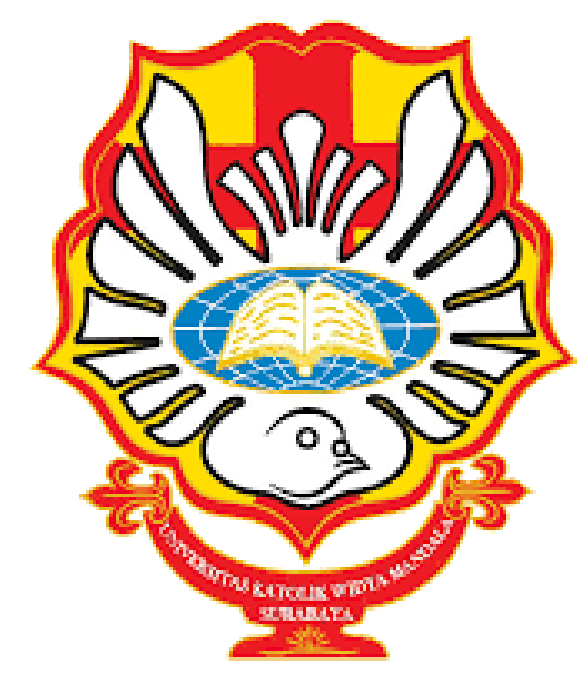

Disusun Oleh :

Arlanda Afi Margono

( Nim: 3903019056 )

UNIVERSITAS KATOLIK WIDYA MANDALA SURABAYA KAMPUS MADIUN 


\begin{abstract}
ABSTRAK
Perang antar suku sering terjadi di Indonesia salah satunya di Papua. Penyebab perang antar suku adalah adanya isu yang belum tentu benarnya atau hoak, serta penyebab lain yaitu karena pendidikan yang belum merata. Akibat perang ini banyak terjadi kerugian mulai rusaknya fasilitas hingga kehilangan nyawa. Saat ini Pancasila sudah mulai goyah, kasus perang antar suku di Papua bertolak belakang dengan Pancasila sila ke tiga dan ke lima. Jika di tinjau dari tujuan negara The Good Life, tujuan dan legitimasi negara pancasila dan gotong royong perang antar suku ini ada kaitannya mulai dari keadilan hingga peenyelesainya perlu gotong royong dan berlandaskan pada Pancasila.
\end{abstract}

Kata kunci : perang antar suku, keadilan, gotong royong 


\section{Perang Antar Suku di Papua}

Perang antar suku di Papua terjadi pada 24 September di Kampung Pagaleme, Distrik Pagalame, Kabupaten Puncak Jaya, Papua. Perang antar suku ini disebabkan oleh pengadangan yang dilakukan kubu BT terhadap KW yang mengakibatkan KW terkena panah dibagian perut pada Senin, dan keesokan harinya BT ditemukan meninggal dunia karena terkena panah yang pelakunya belum diketahui. Karena hal ini akhirnya dari pihak keluarga tidak terima dan akhirnya saling menyerang. Akibat dari perang antar suku ini banyak terjadi kerugian mulai dari rusaknya fasilitas umum serta ada korban jiwa. Perang antar suku ini sering terjadi di Indonesia terutama di daerah pedalam.

Perang antar suku di Papua sudah menelan korban jiwa, selain itu akibat dari perang antar suku ini warga menjadi merasa was-was dan tidak tenang dalam menjalankan aktivitas sehari-hari. Mereka akan takut keluar rumah karena mereka takut bila menjadi sasaran amukan mereka yang sedang berperang. Perang ini juga berpotensi terjadinya perpecahan karena bisa saja akan ada pihak luar yang memanfaatkan situasi ini untuk memecahkan Papua dari Indonesia. Dan akhirnya mereka akan mengambil alih atau mengajak masyarakan Papua untuk ikut dengan mereka dan memberikan jaminan yang menggiyuran. Maka dari itu konflik seperti ini harus segera diselesaikan karena hal ini sudah bertolak belakang dari Pancasila.

Peran pemerintah sangat penting dalam hal ini karena mereka harus lebih meningkatkan keamanan di daerah pedalaman. Serta pemerintah jangan hanya omong kosong saja dengan janji-janji mereka saat pilkada atau pilres, yang hanya membuat janji manis saja saat bermain politik akan tetapi saat terpilih tidak ada kerja nyata. Pendidikan sebaiknya lebih diratakan diseluruh pelosok Indonesia agar saat berita hoak tersebar, mereka tidak akan mudah terpengaruh.

Selain itu media masa lebih ditingkatkan keamanannya agar konflik seperti ini tidak mudah menyebar lewat media masa. Masyarakat didaerah yang pelosok atau pedalaman lebih baik diberi pengetahuan tentang dunia luar seperti tentang hoak atau hal lain yang mengancam persatuan NKRI. 


\section{Tujuan Negara The Good Life}

Dalam kasus perang antar suku di Papua menurut saya ada kaitannya dengan Tujuan Negara The Good Life karena dalam teori ini ada tujuan happines atau kebahagiaan yang di dalamnya terdapat keadilan. Dari sini bisa dilihat bahwa keadilan ini tidak merata di seluruh Indonesia khususnya daerah pedalaman/pelosok. Dapat dilihat bahwa didaerah pelosok ada yang belum terjangkau listrik. Bahkan dalam urusan pendidikan pun belum dikatakan adil, didaerah pelosok ada sekolah ada murid tapi gurunya tidak ada, ada meja tapi tidak ada kursinya, bahkan bangunan yang tak layak pakai pun ada.

Untuk kasus perang antar suku di Papua juga termasuk kurangnya keadilan di daerah sana. Karena pendidikan yang kurang merata didaerah Papua mengakibatkan masyarakat yang masih dikatakan pedalaman hanya akan menggunakan emosi mereka tanpa memikirkan pentingnya musyawarah. Mereka hanya memikirkan nyawa dibalas nyawa tanpa memikirkan apakah orang yang mereka bunuh sudah pasti yang menyebabkan saudara mereka meninggal.

Oleh sebab itu pemerintah jangan hanya diperbaiki infrastrukturnya saja, tetapi juga tenaga yang dapat mengajar didaerah pelosok. Akan sia-sia jika infrastruktur sudah memadai tetapi tenaga pendidik masih minim, karena mereka akan berfikir jika ditempatkan di tempat yang jauh mereka tidak akan leluasa, kesulitan mencari barang, hiburan seperti kehidupan dikota besar.

Agar pendidikan merata di seluruh pelosok Indonesia dan menjadikan sumber daya manusia di Indonesia menjadi lebih berkualitas serta tidak mudah ditipu oleh orang luar. Serta Pancasila bisa terus diterapkan di Indonesia tanpa ada yang mementingkan golongan atau merugikan orang lain. Dan tujuan happines tetap terwujud dan menjadi lebih baik, serta keadilan lebih merata di seluruh pelosok Indonesia. Memang lebih susah untuk menegakkan keadilan di Papua karena budaya mereka yang masih kental, tapi saat ini presiden kita Bapak Jokowi tengah menggencarkan keadilan di seluruh Indonesia yang sangat membawa banyak perubahan. Karena beliau ingin agar seluruh rakyat Indonesia merasakan pembangunan yang sama presiden selalu menegaskan "ini soal keadilan". 


\section{Kaitan Tujuan Dan Legitimasi Negara Pancasila Dengan Perang Antar Suku Di Papua}

Dalam UUD 1945 menulis tujuan dan legitimasi Negara Indonesia yang terdapat di alenia ke empat yang berbunyi :

“... melindungin segenap bangsa Indonesia dan seluruh tumpah darah Indonesia dan untuk memajukan kesejahteraan umum, mencerdaskan kehidupan bangsa, dan ikut melaksanakan ketertiban dunia yang berdasarkan kemerdekaan, perdamaian abadi dan keadilan sosial, maka disusnlah Kemerdekaan........” .

Dari sini dapat kita lihat bahwa tujuan dan legitimasi negara belum sepenuhnya terlaksanakan. Terutama masalah yang menyangkut perang antar suku di Papua yaitu mencerdaskan dan keadilan. Selain itu untuk daerah yang berada di pelosok Indonesia juga banyak yang belum tersentuh oleh UUD 1945 alenia ke empat tersebut.

Karena nyatanya di daerah pedalaman masih sulit mendapat akses untuk menoju kota, jangankan untuk kekota untuk menimba ilmu pun masih kesulitan. Anak-anak yang harus berangkat kesekolah harus menempuh jarak berkilo-kilo meter dan waktu yang cukup lama untuk mencapai kesekolah. Itupun bila perjalanan lancar, karena tidak sedikit yang merasa kelelahan saat perjalanan.

Belum lagi saat menuju kesekolah mereka harus menyeberangi sungai yang tidak ada jembatannya mereka harus melepas baju dan berenang muntuk menyeberangi. Selain bertaruh nyawa karena bisa saja air sungai tiba-tiba debit airnya naik jika dipikir di hutan pasti banyak binatang buas yang berkeliaran. Anak-anak bisa saja di serang oleh binatang buas tersebut.

Selain itu masyarakat Indonesia yang ada di pedalaman yang harus menjual hasil ladang kemungkinan akan menjualnya dinegara tetangga. Karena mereka akan berpikir jika di jual di kota yang menempuh waktu yang cukup lama karena fasilitas jalan yang belum ada atau sulit di akses lebih baik menjual dinegara tetangga yang tidak memerlukan waktu yang lama. Karena jika dipikir-pikir mereka menempuh jarak yang jauh saat sampai pun hasil ladang sudah layu dan akan mengurangi harganya.

Di daerah pedalaman pun juga banyak yang putus sekolah karena biasanya mereka harus pergi ke lain tempat untuk melanjutkan kejenjang pendidikan yang lebih tinggi. Hal ini lah pendidikan di Indonesia sangat minim, mereka akan berpikir lebih baik mereka putus 
sekolah dan bekerja membantu orang tua dan mendapatkan uang. Padahal jika di gali lebih dalam anak-anak daerah pedalaman memiliki semangat belajar yang lebih tinggi

dibandingkan anak di kota-kota besar. Jangankan anak-anak orang dewasa pun juga senang jika mendapatkan tambaham ilmu seperti menghitung dan membaca.

\section{Gotong Royong}

Soekarno mengatakan bahwa prinsip negara ini adalah gotong royong, bahwa tidak boleh ada lagi klaim-klaim golongan, pribadi, dan kelompok apapun hendak memperjuangkan kepentingan mereka sendiri di atas kepentingan bersama. Maka adari itu untuk masalah perang antar suku di Papua ini kita harus bergotong royong dalam hal apapun jangan gegabah dengan mengedepankan emosi. karena bisa berujung pada perpecahan dan akan membuat negara Indonesia menjadi tidak damai lagi.

Kita sebagai bangsa Indoneia harus selalu mengedepan gotong royong dalam kehidupan sehari-hari karena tanpa adanya gotong royong kita tidak dapat melakukan apapun. Karena pada dasarnya manusia adalah makhluk sosial yang saling membutuhkan bantuan orang lain dan kita bisa mati tanpa bantuan orang lain. Dan jangan sampai ada rasis terhadap suku tertentu atau agama tertentu. Karena bila ada masalah seperti itu lama kelamaan Pancasila akan dilupakan dan negara Indonesia akan hancur. Selain itu akan ada banyak konflik yang disebabkan oleh pemaksaan paham/keyakinan suatu kelompok masyarakat tertentu terhadap kelompok masyarakat lainnya. Unsur pemaksaan ini terjadi karena adannya pola pikir sempit atau "fanatisme buta", yaitu para penganutnya yang menjadikan mereka lupa memaknai istilah makhluk sosial.

Selain itu gotong royong memiliki banyak manfaat seperti:

1. Menumbuhkan rasa persatuan, tolong menolong, kebersamaan semakin kuat

2. Mempererat tsli persaudaraan

3. Dapat memupuk kehidupan bermasyarakat, berbangsa dan kebersamaan dengan sesama

4. Menghemat waktu dan tenaga produktivitas kerja

5. Meringankan pekerjaan yang berat menjadi ringan

Maka dari itu dengan adanya gotong royong budaya balas dendam tidak ada. Bisa dibayangkan jika semua suku di Indonesia menganut paham ini, akan runduh negara Indonesia dalam waktu yang singkat. 
Sikap gotong royong juga dapat membuat segala sesuatu lebih mudah. Apalagi saat ini negara kita banyak masuk budaya luar yang berkembang pesat, hal inilah yang membuat gotong royong menjadi luntur. Anak muda menjadi lebih antisosial, karena sibuk dengan gadget mereka. Jika dilihat dari tingkat interaksi sosial mereka dapat dengan mudah berinteraks, lebih dekat dan lebih mengenal dengan teman atau saudara yang berada ribuan kilometer tinggalnya. Tapi mereka lupa dengan teman atau saudara yang berada didekatnya atau bahkan merreka tidak mengenal baik.

Kita patut bersyukur bisa disatukan dalam konsep Indonesia yang menganut Pancasila sebagai pedoman dasarnya. Pada sila pertama Ketuhanan Yang Maha Esa kita bisa disatukan untuk bisa menuju Keadilan Sosial Bagi Seluruh Rakyat Indonesia dengan cara bergotong royong. Jadi Pancasila dengan gotong royong tidak boleh dipisahkan karena sudah merupakan satu kesatuan. Sesuai dengan pidato Soekarno “Jikalau saya peras yang lima menjadi tiga, dan yang tiga menjadi satu, maka dapatlah saya satu perkataan "gotong royong”. Alangkah hebatnya! Negara Gotong Royong!”.

Jadi, untuk masalah perang antar suku di Papua kita harus bergotong royong menyelesaikanya. Papua akan tetap dan memang sepenuhnya merupakan bagian dari Indonesia. Kita ingin semua daerah maju dan tidak ingin salah satu daerah kita ada yang tertinggal dan ada masalah berkaitan dengan keamanan dan keadilan. Jangan sampai usaha Soekarno dan para pejuang lain sia-sia, selain itu lebih baik saat terjadi perang antar suku atau ada konflik apapun lebih diperketat keamanan baik media masa atau apapun agar situasi tidak semakin memanas serta tidak ada pihak luar yang memanfaatkan situasi tersebut untuk merebut daerah tersebut. Dan bila ada masalah segeralah bergotong royong menyelesaikannya jangan langsung menggunakan kekerasan atau budaya balas dendam. 


\section{DAFTAR PUSTAKA}

Dewantara, A. W. (2017). Alangkah hebatnya negara gotong royong: Indonesia dalam kacamata Soekarno. PT Kanisius.

DEWANTARA, A. W. (2016). GOTONG-ROYONG MENURUT SOEKARNO DALAM PERSPEKTIF AKSIOLOGI MAX SCHELER, DAN SUMBANGANNYA BAGI NASIONALISME INDONESIA (Doctoral dissertation, Universitas Gadjah Mada).

Dewantara, A. W. (2013). Merefleksikan Hubungan antara Etika Aristotelian dan Bisnis dengan Studi Kasus Lumpur Lapindo. Arete, 2(1), 23-40.

Dewantara, A. W. (2015). Filosofi Pendidikan yang Integral dan Humanis dalam Perspektif Mangunwijaya. JPAK: Jurnal Pendidikan Agama Katolik, 13(7), 3-9.

Dewantara, A. W. (2018). Pendidikan Kewarganegaraan. Madiun: STKIP Widya Yuwana. 